\title{
Dysfunctional family environments and childhood psychopathology: the role of psychiatric comorbidity
}

\author{
Ambientes de famílias disfuncionais e psicopatologia infantil: \\ o papel da comorbidade psiquiátrica
}

Suzielle M. Flores, ${ }^{1}$ Giovanni A. Salum, ${ }^{2}$ Gisele G. Manfro ${ }^{2}$

\begin{abstract}
Introduction: The study of the association between specific characteristics of family environments and different types of psychopathology may contribute to our understanding of these complex disorders and ultimately inform therapeutics.

Objective: To compare the family characteristics of four groups: typically developing children; children with anxiety disorders only; children with externalizing disorders only; and children with both anxiety and externalizing disorders.

Methods: This study enrolled 115 individuals from the community. Child psychiatrists made psychiatric diagnoses using a structured clinical interview. The Family Environment scale was used to evaluate six domains of family function.

Results: The group with both anxiety and externalizing disorders had higher levels of conflict in family environment and lower levels of organization when compared with typically developing children. In addition, internalizing and externalizing symptoms were positively associated with conflict and negatively with organization. Maternal depressive and anxious symptoms were also associated with higher conflict and lower organization scores. Conclusion: An important between-group difference in comorbid cases of anxiety and behavioral disorders suggests that children with this comorbidity are potential candidates for family interventions to address family conflicts and organizational aspects.

Keywords: Anxiety, phobias, family, comorbidity, ADHD.
\end{abstract}

\begin{abstract}
Resumo
Introdução: $O$ estudo da relação entre características específicas do ambiente familiar e os diferentes tipos de psicopatologias pode contribuir para o nosso entendimento desses complexos transtornos e possivelmente gerar informações para seu tratamento.

Objetivo: Comparar as características familiares de quatro grupos: Crianças com desenvolvimento típico; crianças com transtornos de ansiedade apenas; crianças com transtornos de externalização apenas; e crianças com transtornos de ansiedade e de externalização.
\end{abstract}

Métodos: Cento e quinze indivíduos foram recrutados na comunidade. Psiquiatras pediátricos usaram uma entrevista clínica estruturada para estabelecer os diagnósticos psiquiátricos. A Escala do Ambiente Familiar (Family Environment) foi usada para avaliar os seis domínios de funcionamento da família.

Resultados: $O$ grupo que apresentava tanto transtornos de ansiedade quanto de externalização apresentou níveis mais altos de conflito e níveis mais baixos de organização quando comparados com as crianças com desenvolvimento típico. Além disso, os sintomas de externalização e internalização estavam positivamente relacionados a conflitos e negativamente a organização. Sintomas depressivos e de ansiedade da mãe também se mostraram relacionados a resultados mais altos para conflito e mais baixos para organização.

Conclusão: Uma importante diferença entre grupos em casos de comorbidades de transtornos de ansiedade e de comportamento sugerem que as crianças com esta comorbidades são candidatos em potencial para intervenções familiares que abordem conflitos familiares e aspectos organizacionais.

Descritores: Ansiedade, fobias, família, comorbidade, TDAH.

\footnotetext{
${ }^{1}$ Medical student, Universidade Federal do Rio Grande do Sul (UFRGS), Porto Alegre, RS, Brazil. ${ }^{2}$ MD, PhD. Graduate Program in Medical Sciences: Psychiatry, UFRGS, Porto Alegre, RS, Brazil. Anxiety Disorders Program, Hospital de Clínicas de Porto Alegre (HCPA), Porto Alegre, RS, Brazil.

Financial support: Fundo de Incentivo à Pesquisa e Eventos - Hospital de Clínicas de Porto Alegre (FIPE/HCPA; 08-017), Conselho Nacional de Desenvolvimento Científico e Tecnológico (CNPq; 483032/2007-7 and scholarship 305524/2009-7), and Coordenação de Aperfeiçoamento de Pessoal de Nível Superior - Fundação de Amparo à Pesquisa do Estado do Rio Grande do Sul (CAPES-FAPERGS; scholarship 2842-25.51/12-0).

Submitted Mar 03 2014, accepted for publication Jun 12 2014. No conflicts of interest declared concerning the publication of this article.

Suggested citation: Flores SM, Salum GA, Manfro GG. Dysfunctional family environments and childhood psychopathology: the role of psychiatric comorbidity. Trends Psychiatry Psychother. 2014;36(3):147-151. http://dx.doi.org/10.1590/2237-6089-2014-0003
} 


\section{Introduction}

Family environment may be defined as the result of the quality of interpersonal relationships, personal growth and system maintenance among family members, and characterized by factors such as cohesion, harmony and the ability to deal with conflicting problems. ${ }^{1}$ These characteristics may impact children's experiences, life trajectories and emotional development and have been previously associated with mental disorders. ${ }^{2}$ Family environment may be a critical early contribution to the risk of psychopathology, but it is not known whether specific characteristics of family environment may diversely contribute to different types of psychiatric disorders, such as internalizing and externalizing disorders and comorbid disorders. The study of possible associations with family environment may add to our understanding of these complex disorders and ultimately inform therapeutics.

Some studies have used instruments that assess different characteristics of family environment (e.g., levels of conflict, cohesion, control), such as the Family Environment Scale (FES). ${ }^{1}$ These studies have found that children with externalizing disorders, such as attention deficit hyperactivity disorder (ADHD), live in dysfunctional family environments characterized by low cohesion and high conflict between family members. ${ }^{3,4}$ Families of children with ADHD had more adversity factors than families of typically developing children.5,6 Studies with children with depression also found higher levels of conflict and lower levels of cohesion, expressiveness and active-recreational orientation when compared with families of children without mental illnesses. ${ }^{7}$ In addition, preliminary evidence suggested that patients with comorbid ADHD and anxiety disorder had families with higher levels of conflict than controls and individuals with ADHD only. ${ }^{8}$

Nevertheless, studies that investigated different aspects of family environment and psychopathology are still scarce. To the authors' knowledge, no studies have investigated aspects of family environment in groups of children with anxiety disorders alone. The main aim of this study was to compare the family characteristics of four groups: typically developing children (controls), children with anxiety disorders only or externalizing disorders only, and children with both anxiety and externalizing disorders. Our initial hypothesis was that families of children with externalizing disorders would be associated with high conflict scores. Because of lack of data, no specific predictions were made for children with anxiety disorders only or for comorbid groups.

\section{Methods}

This study was approved by the Ethics Committee of Hospital de Clínicas de Porto Alegre (number 08-017), Brazil. Details about the study design can be found elsewhere. ${ }^{9}$ Briefly, children from six public schools in Porto Alegre, who rated above the 75th percentile in the Screen for Child Anxiety Related Emotional Disorders (SCARED) scale, ${ }^{10,11}$ and their parents were invited to undergo a diagnostic evaluation using a clinical interview and a structured psychiatric interview assessed by the Schedule for Affective Disorder and Schizophrenia for School-Age Children - Present and Lifetime Version (K-SADS-PL). ${ }^{12}$ Additionally, a random sample of controls equally distributed in the other three quartiles of the SCARED scale was also invited to participate in the same psychiatric evaluation. One hundred and fifteen children aged 10 to 17 years and their biological parents (father or mother) accepted to participate in this study. They all came from the same community, but from different families, and they all provided written consent. They were grouped into four non-overlapping categories according to the K-SADSPL diagnosis: 14 children and adolescents with externalizing disorders (attention deficit/hyperactivity disorder or oppositional defiant disorder), 42 with anxiety disorders (separation anxiety disorder, generalized anxiety disorder, panic disorder or social anxiety disorder), 21 with both anxiety and behavioral disorders, and 38 typically developing children. Individuals with 1) significant organic illness, 2) history of bipolar disorder, pervasive developmental disorder or any psychotic disorder, 3) history of alcohol or drug dependence or abuse, 4) clinical suspicious of mental retardation, or 5) current depression were excluded from this study. However, individuals with a diagnosis of specific phobia were allowed in all groups, because specific phobias alone are not very common developmental disorders and have spontaneous remission in many children and adolescents. ${ }^{13}$

Family functioning was assessed using a validated Portuguese version of $\mathrm{FES}^{1}{ }^{1}$ rated by the principal caregiver of the child. The FES scale is composed of six subscales divided into three different domains: 1) interpersonal relationships dimension (cohesion, expressivity and conflict subscales); 2) personal growth dimension (achievement-oriented subscale); and 3) system maintenance dimension (control and organization subscales). We also assessed other psychiatric dimensional symptoms using the SCARED scale and the Strengths and Difficulties Questionnaire (SDQ). These scales are validated self-applied questionnaires answered by the parents and were used 
to assess the frequency and intensity of anxiety and externalizing symptoms. The Beck Anxiety Inventory (BAI) and the Beck Depression Inventory (BDI) were used to investigate maternal anxiety and depressive symptoms. Multivariate analysis of variance (MANOVA) was used to compare general family functioning between groups. All statistical assumptions for the use of MANOVA were met. As the FES subscales had normal distributions, equality of error variances and covariance matrices were also used, and the type III sum of squares was used to account for unequal cell sizes. Other results were analyzed using analysis of variance (ANOVA) and the Tukey post-hoc test to correct for multiple testing.

\section{Results}

MANOVA results revealed that the four groups differed significantly in general aspects of family functioning (Roy's largest root $=1.161, \mathrm{~F}_{6,108}=3.17, \mathrm{p}$ $=0.007, \eta p 2=0.150)$. Additional ANOVA revealed that groups differed in two specific FES subscales, conflict and organization (Table 1). Post-hoc tests showed that the group with both anxiety and behavioral disorders had higher levels of conflict in family environment and lower levels of organization than typically developing controls. No differences were found between the groups of anxiety only and behavioral disorders only when compared to typically developing controls or comorbid groups.

In general, conflict scores were positively correlated with anxiety symptoms of panic, generalized anxiety and school phobia evaluated using the SCARED scale, but organization scores were negatively correlated with behavioral symptoms of hyperactivity and conduct assessed by the SDQ. In addition, maternal depressive and anxious symptoms were also associated with higher conflict scores and lower organization scores. No consistent differences emerged for control, achievement orientation and expressivity scales for anxiety or hyperactivity symptoms. All correlations were modest (Table 2).

\section{Discussion}

In this study, parents of children and adolescents with comorbid anxiety and externalizing disorders were more likely to report having family environments characterized by higher rates of conflict between members and lower rates of organization than the parents of typically developing children. Furthermore, these two family environment scores were also associated with anxiety and externalizing dimensional symptoms in our sample.
Conflict is characterized by a family environment marked by disagreements about ideas or feelings, which leads to poorer family functioning, whereas family organization refers to the arrangement or programing of activities among family members. ${ }^{1}$ Our findings are in agreement with those reported by Kepley et al., ${ }^{8}$ who also found higher conflict scores in families of children with comorbid ADHD and anxiety disorder than in families of a control group. On the other hand, differently from our results, their study found that the presence of ADHD along with a comorbid anxiety disorder was associated with a family environment that is unusually insular, dependent, and discouraging of autonomy. ${ }^{8}$

Our findings of a worse family functioning in the comorbid group, but not in the anxiety or behavioral disorder groups, may reflect differences in symptom severity between those groups, as we also found that both conflict and organization were associated with anxiety and hyperactivity scores dimensionally. In spite of that, we did not find differences in SCARED and SDQ hyperactivity scores between single-disorder and comorbid groups. Small nominal (non-significant) differences that we were not able to detect might have potentially been driving our results of the comorbid group, as our sample was not clinically referred and all individuals were recruited in the community. Levels of anxiety and externalizing symptoms in single-disorder groups in our sample might have been insufficient to generate family dysfunction at lower symptomatic levels. Alternatively, family dysfunction levels might not have been sufficient to produce greater symptom changes, as the nature of our cross-sectional design might not lead to a causal effect.

Also in accordance to previous findings, 5,14 maternal symptoms of anxiety and depression were associated with higher levels of conflict and lower levels of organization in family environment in our study. Again, we were not able to find differences between groups in symptoms of anxiety and depression in mothers, but the comorbid groups had higher nominal levels of anxiety, as assessed by the BAI. These specific differences reflect the complexity of the interaction between psychiatric symptoms and family functioning, which is subjected to passive and active gene-environment correlations and actual environmental effects. ${ }^{15}$

Some limitations of this study are its cross-sectional design, a strictly correlational nature and a small sample size in a non-representative sample. A type II error should be considered for the lack of significant differences between the same subscales and non-comorbid conditions, as the nominal values suggest that a potentially smaller 
effect may be present. A type I error due to multiple comparisons may also be present. However, to avoid a type I error, we used a stepwise approach. MANOVA was used to detect whether there was an overall difference in family environment between groups; ANOVA for each FES domain and post hoc tests were used to correct for multiple comparisons for all significant differences. In addition, our study evaluated only aspects of family environment, but data on family structure, such as number of family members, may also contribute to the results that we found.

Table 1 - Clinical characteristics of the sample and FES, SCARED, SDQ, BDI and BAI scores

\begin{tabular}{|c|c|c|c|c|c|c|c|c|c|c|c|}
\hline & \multicolumn{2}{|c|}{$\begin{array}{c}\text { TDC } \\
(\mathrm{n}=38)\end{array}$} & \multicolumn{2}{|c|}{$\begin{array}{c}\text { Only } \\
\text { externalizing } \\
\text { disorders } \\
(\mathbf{n}=14)\end{array}$} & \multicolumn{2}{|c|}{$\begin{array}{c}\text { Only anxiety } \\
\text { disorders } \\
(n=42)\end{array}$} & \multicolumn{2}{|c|}{$\begin{array}{c}\text { Both } \\
\text { anxiety and } \\
\text { externalizing } \\
\text { disorders } \\
(\mathbf{n}=\mathbf{2 1})\end{array}$} & \multirow[b]{2}{*}{ Statistics } & \multirow[b]{2}{*}{$\mathbf{p}$} & \multirow[b]{2}{*}{ ES } \\
\hline & $n$ & $\%$ & $n$ & $\%$ & $n$ & $\%$ & $\mathbf{n}$ & $\%$ & & & \\
\hline Sex (female) & 24 & 63.2 & 9 & 64.30 & 31 & 73.80 & 13 & 62.20 & $\chi^{2}(3)=1.42$ & 0.699 & - \\
\hline \multicolumn{12}{|l|}{ DSM-IV diagnosis } \\
\hline ADHD & - & - & 12 & 85.70 & & - & 15 & 71.40 & & & \\
\hline ODD & - & - & 7 & 50.00 & & - & 8 & 38.10 & & & \\
\hline $\mathrm{CD}$ & - & - & 1 & 7.10 & & - & 0 & 0.00 & & & \\
\hline Panic & - & - & 0 & - & 1 & 2.40 & 1 & 4.80 & & & \\
\hline Separation anxiety & - & - & 0 & - & 11 & 26.20 & 5 & 23.80 & & & \\
\hline Social anxiety & - & - & 0 & - & 16 & 38.10 & 9 & 42.90 & & & \\
\hline GAD & - & - & 0 & - & 31 & 73.80 & 16 & 76.20 & & & \\
\hline Specific phobia & 7 & 18.40 & 5 & 35.70 & 22 & 52.40 & 8 & 38.10 & & & \\
\hline \multicolumn{12}{|l|}{ Parental demographics } \\
\hline Maternal education & & & & & & & & & $\chi^{2}(6)=10.8$ & 0.093 & \\
\hline Very low & 4 & 10.5 & 0 & 0.0 & 6 & 14.3 & 1 & 4.8 & & & \\
\hline Low & 12 & 31.6 & 3 & 23.1 & 18 & 42.9 & 13 & 61.9 & & & \\
\hline High & 22 & 57.9 & 10 & 76.9 & 18 & 42.9 & 7 & 33.3 & & & \\
\hline Marital status & & & & & & & & & $\chi^{2}(9)=13.1$ & 0.154 & \\
\hline Single & 5 & 13.2 & 2 & 14.3 & 6 & 14.3 & 2 & 9.5 & & & \\
\hline Married & 27 & 71.1 & 6 & 42.9 & 21 & 50.0 & 15 & 71.4 & & & \\
\hline Separated & 5 & 13.2 & 3 & 21.4 & 13 & 31.0 & 2 & 9.5 & & & \\
\hline \multirow[t]{2}{*}{ Widowed } & 1 & 2.6 & 3 & 21.4 & 2 & 4.8 & 2 & 9.5 & & & \\
\hline & M & SD & $\mathbf{M}$ & SD & $\mathbf{M}$ & SD & M & SD & $F_{3,111}$ & $\mathbf{p}$ & $\eta_{p}^{2}$ \\
\hline Age (years) & 13.07 & 2.46 & 13.37 & 2.22 & 13.26 & 2.3 & 13.42 & 2.29 & 0.062 & 0.98 & 0.002 \\
\hline \multicolumn{12}{|l|}{ FES domains } \\
\hline Cohesion & 7.42 & 1.52 & 6.36 & 2.44 & 6.45 & 2.17 & 6.52 & 1.86 & 2.094 & 0.105 & 0.054 \\
\hline Conflict & $2.03^{a}$ & 1.85 & $3.29^{a, b}$ & 2.33 & $2.83^{a, b}$ & 2.33 & $3.57^{b}$ & 1.63 & 3.003 & 0.034 & 0.075 \\
\hline Control & 5.11 & 1.93 & 5.57 & 1.4 & 4.6 & 2.13 & 4.81 & 2.04 & 1.021 & 0.386 & 0.027 \\
\hline Organization & $6.71^{\mathrm{a}}$ & 2.07 & $5.21^{a, b}$ & 1.89 & $5.67^{a, b}$ & 2.24 & $4.71^{\mathrm{b}}$ & 2.26 & 4.466 & 0.005 & 0.108 \\
\hline $\begin{array}{l}\text { Achievement } \\
\text { orientation }\end{array}$ & 5.87 & 1.44 & 5.43 & 1.74 & 5.79 & 1.41 & 6.1 & 1.37 & 0.61 & 0.61 & 0.016 \\
\hline Expressivity & 4.74 & 1.37 & 4.64 & 1.15 & 4.62 & 1.62 & 4.76 & 1.58 & 0.066 & 0.978 & 0.002 \\
\hline Child symptoms & & & & & & & & & $F_{3,108}$ & & \\
\hline SCARED & $14.11^{\mathrm{a}}$ & 9.88 & $18.07^{b}$ & 9.48 & $24.48^{\mathrm{b}, \mathrm{c}}$ & 13.96 & $29.86^{c}$ & 9.40 & 10.204 & $<0.001$ & 0.753 \\
\hline \multicolumn{12}{|l|}{ SDQ } \\
\hline Emotional & $3.03^{a}$ & 1.85 & $5.07^{b}$ & 2.37 & $5.27^{b}$ & 2.25 & $5.68^{\mathrm{b}}$ & 2.5 & 7.706 & $<0.001$ & 0.176 \\
\hline Conduct & $1.79^{a}$ & 1.49 & $4.27^{b}$ & 2.99 & $3.24^{b}$ & 2.2 & $4.45^{\mathrm{b}}$ & 1.63 & 10.344 & $<0.001$ & 0.223 \\
\hline Hyperactivity & $3.05^{\mathrm{a}}$ & 1.67 & $6^{b}$ & 1.81 & $4.32^{\mathrm{b}}$ & 2.18 & $5.27^{b}$ & 2.16 & 9.424 & $<0.001$ & 0.207 \\
\hline Peer relationship & $2^{\mathrm{a}}$ & 1.49 & $2.4^{\mathrm{a}, \mathrm{b}}$ & 1.45 & $3.29^{b}$ & 1.98 & $2.77^{a, b}$ & 1.74 & 2.939 & 0.037 & 0.075 \\
\hline Pro-social Behavior & 8.05 & 1.47 & 7.47 & 2.45 & 7.87 & 1.87 & 8.32 & 1.49 & 0.737 & 0.532 & 0.02 \\
\hline Total & 10 & 4.06 & 17.73 & 5.75 & 16 & 5.29 & 18.18 & 5.53 & 15.635 & $<0.001$ & 0.303 \\
\hline Maternal symptoms & & & & & & & & & $F_{3,107}$ & & \\
\hline BDI (depression) & 10.43 & 7.29 & 13.54 & 10.68 & 11.93 & 7.45 & 12.62 & 9.22 & 0.605 & 0.613 & 0.017 \\
\hline BAI (anxiety) & 11.35 & 10.55 & 15.79 & 13.84 & 12.12 & 10.94 & 19.05 & 10.3 & 2.427 & 0.07 & 0.064 \\
\hline \multicolumn{12}{|l|}{ Parental demographics } \\
\hline Maternal age & 41.53 & 7.56 & 41.86 & 6.54 & 41.55 & 7.52 & 38.58 & 9.56 & $\mathrm{~F}_{3,105}=0.78$ & 0.506 & 0.022 \\
\hline Paternal age & 43 & 6.38 & 42.88 & 7.47 & 44.04 & 10.35 & 44.38 & 9.87 & $F_{3,68}=0.121$ & 0.947 & 0.005 \\
\hline
\end{tabular}

$\mathrm{ADHD}=$ attention deficit hyperactivity disorder; BAI = Beck Anxiety Inventory; BDI = Beck Depression Inventory; CD = conduct disorder; DSM-IV = Diagnostic and Statistical Manual of Mental Disorders, 4th edition; ES = effect size; FES = Family Environment Scale; GAD = generalized anxiety disorder; $M=$ mean; ODD = oppositional defiant disorder; SCARED = Screen for Children and Anxiety Related Emotional Disorders; SD = standard deviation; SDQ = Strengths and Difficulties Questionnaire; TDC = typically developing controls.

Different superscript letters indicate statistically significant differences in post hoc tests (Tukey), and equal letters indicate differences that were not statistically significant. 
Table 2 - Pearson correlations between FES scores and SACRED, SDQ, BAI and BDI subscale scores

\begin{tabular}{|c|c|c|c|c|c|c|}
\hline & \multicolumn{6}{|c|}{ FES domains } \\
\hline & Cohesion & Conflict & Control & Organization & $\begin{array}{c}\text { Achievement } \\
\text { orientation }\end{array}$ & Expressiveness \\
\hline \multicolumn{7}{|l|}{ Child symptoms } \\
\hline \multicolumn{7}{|l|}{ SCARED (parent-rated) } \\
\hline Panic & -0.116 & 0.173 & 0.115 & $-0.183 *$ & 0.02 & -0.11 \\
\hline GAD & -0.056 & $0.192 *$ & 0.063 & $-0.190 *$ & 0.086 & -0.076 \\
\hline Separation anxiety & -0.052 & 0.135 & 0.02 & -0.159 & 0.083 & 0.011 \\
\hline School phobia & $-0.205^{*}$ & $0.183^{*}$ & 0.029 & $-0.197 *$ & 0.061 & -0.134 \\
\hline Social anxiety & -0.137 & 0.086 & -0.016 & -0.159 & 0.056 & -0.072 \\
\hline Total & -0.124 & $0.202 *$ & 0.065 & $-0.229 *$ & 0.079 & -0.091 \\
\hline \multicolumn{7}{|l|}{ SDQ (child-rated) } \\
\hline Emotional & -0.055 & $0.233^{+}$ & 0.064 & 0.074 & $0.206^{*}$ & -0.095 \\
\hline Conduct & -0.107 & $0.231 *$ & 0.135 & -0.155 & 0.147 & -0.006 \\
\hline Hyperactivity & -0.154 & $0.190 *$ & -0.04 & $-0.192 *$ & 0.053 & -0.085 \\
\hline Peer-relationship & $-0.189 *$ & 0.045 & 0.167 & -0.094 & -0.053 & 0.022 \\
\hline Pro-social behavior & $0.206 *$ & 0.075 & 0.074 & 0.073 & -0.023 & 0.008 \\
\hline Total & -0.17 & $0.276^{+}$ & 0.099 & -0.116 & 0.134 & -0.056 \\
\hline \multicolumn{7}{|l|}{ Maternal symptoms } \\
\hline BAI & -0.146 & $0.180^{*}$ & 0.004 & $-0.297^{+}$ & -0.166 & -0.138 \\
\hline BDI & $-.0197 *$ & $0.182 *$ & 0.028 & $-0.241^{+}$ & -0.096 & -0.113 \\
\hline
\end{tabular}

$\mathrm{BAI}=$ Beck Anxiety Inventory; BDI = Beck Depression Inventory; FES = Family Environment Scale; GAD = generalized anxiety disorder; SCARED = Screen for Children and Anxiety Related Emotional Disorders; SDQ = Strengths and Difficulties Questionnaire.

* Correlation is significant at the 0.05 level (two-tailed); ${ }^{\dagger}$ correlation is significant at the 0.01 level (two-tailed).

Despite that, we found an important between-group difference with a moderate effect size in comorbid cases of anxiety and behavioral disorders, which suggests that comorbid cases of anxiety and behavioral disorders are potential candidates for family interventions that address family conflict and organization.

\section{References}

1. Vianna VP, Silva EA, Souza-Formigoni ML. [Portuguese version of the Family Environment Scale: application and validation]. Rev Saude Publica. 2007;41:419-26.

2. Rutter M, Cox A, Tupling C, Berger M, Yule W. Attainment and adjustment in two geographical areas. I--The prevalence of psychiatric disorder. Br J Psychiatry. 1975;126:493-509.

3. Pressman LJ, Loo SK, Carpenter EM, Asarnow JR, Lynn D, McCracken JT, et al. Relationship of family environment and parental psychiatric diagnosis to impairment in ADHD. J Am Acad Child Adolesc Psychiatry. 2006;45:346-54.

4. Pheula GF, Rohde LA, Schmitz M. Are family variables associated with ADHD, inattentive type? A case-control study in schools. Eur Child Adolesc Psychiatry. 2011;20:137-45. Epub 2011 Feb 3.

5. Biederman J, Milberger S, Faraone SV, Kiely K, Guite J, Mick $E$, et al. Family-environment risk factors for attention-deficit hyperactivity disorder. A test of Rutter's indicators of adversity. Arch Gen Psychiatry. 1995;52:464-70.

6. Biederman J, Milberger S, Faraone SV, Kiely K, Guite J, Mick E, et al. Impact of adversity on functioning and comorbidity in children with attention-deficit hyperactivity disorder. J Am Acad Child Adolesc Psychiatry. 1995;34:1495-503.

7. Ogburn KM, Sanches M, Williamson DE, Caetano SC, Olvera RL, Pliszka S, et al. Family environment and pediatric major depressive disorder. Psychopathology. 2010;43:312-8. Epub 2010 Jul 28.
8. Kepley HO, Ostrander R. Family characteristics of anxious ADHD children: preliminary results. J Atten Disord. 2007;10:317-23.

9. Salum GA, Isolan LR, Bosa VL, Tocchetto AG, Teche SP, Schuch I, et al. The multidimensional evaluation and treatment of anxiety in children and adolescents: rationale, design, methods and preliminary findings. Rev Bras Psiquiatr. 2011;33:181-95.

10. Birmaher B, Brent DA, Chiappetta L, Bridge J, Monga S, Baugher M. Psychometric properties of the Screen for Child Anxiety Related Emotional Disorders (SCARED): a replication study. J Am Acad Child Adolesc Psychiatry. 1999;38:1230-6.

11. Isolan L, Salum GA, Osowski AT, Amaro E, Manfro GG. Psychometric properties of the Screen for Child Anxiety Related Emotional Disorders (SCARED) in Brazilian children and adolescents. J Anxiety Disord. 2011;25:741-8. Epub 2011 Apr 4.

12. Kaufman J, Birmaher B, Brent D, Rao U, Flynn C, Moreci P. Schedule for Affective Disorders and Schizophrenia for SchoolAge Children-Present and Lifetime Version (K-SADS-PL): initial reliability and validity data. J Am Acad Child Adolesc Psychiatry. 1997;36:980-8.

13. Klein RG. Anxiety disorders. J Child Psychol Psychiatry. 2009; 50:153-62.

14. Hughes AA, Hedtke KA, Kendall PC. Family functioning in families of children with anxiety disorders. J Fam Psychol. 2008;22:325-8.

15. Polanczyk GV. Searching for the developmental origins of mental disorders. Rev Psiquiatr Rio Gd Sul. 2009;31:6-12.

\section{Correspondence:}

Gisele Gus Manfro

Hospital de Clínicas de Porto Alegre

Rua Ramiro Barcelos, 2350

90035-003 - Porto Alegre, RS - Brazil

E-mail: gmanfro@gmail.com 